\title{
BUSINESS PERFORMANCE MANAGEMENT AND FDI: KEY DIFFERENCES BETWEEN FOREIGN AND DOMESTIC-OWNED FIRMS - A CASE OF SLOVAKIA
}

\author{
Rastislav RAJNOHA ${ }^{1^{*}}$, Martina MERKOVÁ2 ${ }^{2}$,án DOBROVIČ ${ }^{3}$, Zoltán RÓZSA ${ }^{4}$ \\ ${ }^{1}$ Faculty of Management and Economics, Tomas Bata University in Zlin, \\ nám. T. G. Masaryka 5555, 76001 Zlín, Czech Republic \\ ${ }^{2}$ Department of Business Economics, Technical University in Zvolen, \\ ul. T. G. Masaryka 2117/24, 96053 Zvolen, Slovakia \\ ${ }^{3}$ Faculty of Management, University of Prešov, ul. 17. novembra 15, 08001 Prešov, Slovakia \\ ${ }^{4}$ Department of Management, School of Economics of Public Administration Management \\ in Bratislava, Furdekova 16, 85104 Bratislava 5, Slovakia
}

Received 14 October 2017; accepted 01 March 2018

\begin{abstract}
The empirical study defines typical investment behaviour of foreign-owned firms against local firms and highlights benefits and any discrepancies of foreign capital. The paper focuses on industrial enterprises in Slovakia mainly from the automotive, engineering and wood-processing industry $(\mathrm{N}=164)$. Results show the significant dependence of foreign ownership and better business performance compared with domestic firms. The performance was expressed through ROE indicator. Enterprises with the foreign participation of property achieve better performance, most typically with ROE above $10 \%$ (p-value $<0.05$ ). The better performance, as well as distinctive feature of intangibles and research \& development investments, are typically in foreign-owned firms. Intangibles and R\&D as crucial investments do not directly cause better business performance in foreign-owned firms, and we discuss the reasons. The research results offer relevant and interesting implications for managers behaviour, also public authorities as well as motives for further investigation of the business performance management and foreign direct investment issues.
\end{abstract}

Keywords: business economics, business performance management, foreign direct investment, intangibles, foreign-owned firms, $R \& D$ investments.

JEL Classification: M21, M16, F21.

\section{Introduction}

FDI (Foreign Direct Investment) by multinational corporations (MNCs) a significant role in the transformation of former centrally planned economies (Chidlow et al. 2009; Fisher et al. 2007; Giroud 2007). "The cumulative level of FDI is particularly high in those countries in

${ }^{\star}$ Corresponding author. E-mail: rajnoha@fame.utb.cz 
which the transformation process was evaluated to be positive" (Beyer 2002; Ferenčíková, Dudáš 2005). Gradual growth of FDI inflows in the last twenty years has led to the emergence and expansion of new industries. A good example is the automotive industry, which belongs today in Central Europe to the principal industries (Dudáš, Lukáč 2014). Many economic measures were undertaken since 2002 aimed at providing a business-friendly environment (Fisher et al. 2007; Giroud 2007; Virglerová et al. 2016, 2017; Ključnikov et al. 2016). Transition economies have to host inward-FDI to stay competitive (Fabry, Zeghni 2006). "FDI may help to achieve upgrading of industry and improve productivity by importing high-tech technologies and new knowledge base" (Fabry, Zeghni 2006; Kalotay 2002; Bevan, Estrin 2004; Horta et al. 2016). The eclectic or OLI paradigm of FDI comprises three sets of interdependent variables (Dunning 2000): ownership-specific advantages, location and internalisation benefits. The fourth, home-country advantage (Kalotay, Sulstarová 2010), what means home-country environment, may especially occur in the specific conditions of emerging economies. FDI brings significant effects, among other things, regarding their higher competitiveness and performance (Perkmann 2006). We attempted them to identify and quantify in our empirical research conducted in conditions of the economy in Central Eastern Europe country - Slovakia.

The research was conducted on a sample of randomly selected industry firms in Slovakia mainly from the automotive, engineering and wood-processing industry. The core of mentioned research was at first to define specific parameters that are characteristic for the highest performance, but also to point the parameters that cause only average or low performance. Rajnoha et al. (2013) published the research results and demonstrated the significant impact of the participation of foreign capital in the business performance. The primary objective of this research has not been to analyse the effects of FDI, but just foreign capital (partial of fully foreign ownership) as a significant factor for achieving higher performance of enterprises is an important parameter of our research.

The objective of this paper, where we publish one part of our research, was to analyse the area of investment management in companies and its impact on business performance. We investigated main differences between foreign and domestic-owned firms.

The following hypotheses were identified:

1. Foreign ownership is in a relationship with better business performance.

2. Firms, whose origin of foreign capital is from Germany, are the most-performing companies, considering the traditional business relationship of Slovakia just with Germany.

3. Opposite the domestic firms investing allover, foreign-owned firms mostly invest in certain - crucial kind of investment.

4. Just significant investment in case of foreign-owned firms causes better business performance.

As appears from the above, defined hypotheses as the starting point of the research relate to foreign enterprises, their typical behaviour in the scope of investment and significant differences from domestic firms influencing the business performance in the end. 


\section{Theory and literature review}

The examination of the performance management and measurement system worldwide, in former centrally planned economies and also especially in condition of Czech Republic and Slovakia is dedicated several research studies: the strategic orientation in the performance management (Morgan, Strong 2003); the SPMS - strategic measurement performance system (Bisbe, Malagueňo 2012; Gimbert et al. 2010); the impact of corporate governance on business performances in Romania (Achim et al. 2016); the role of SME sector in the economy and necessity of innovations and entrepreneurship in business in the era of global competition (Czarniewski 2016); the SPMS on the base of managerial information support and Business Intelligence (Rajnoha et al. 2016; Zámečník, Rajnoha 2015); the business process performance measurement system (Tuček et al. 2013); a model for the entrepreneurial orientation measurement (Belás, Sopková 2016); the model of specific factors in performance management (Rajnoha, Lesníková 2016); the model of specific factors in foreign trade (Dubravská et al. 2015); analysis of a key competitive factor in the steel industry in Slovakia and Poland (Štefko et al. 2012); the relationship between customer satisfaction and financial performance on the case of banking sector (Belás, Gabčová 2016; Korauš et al. 2015); the impact of the use of BSC on financial business performance in Czech Republic (Knápková et al. 2014); the critical success factors of implementation of the BSC (Šoltés, Gavurová 2015); the combination the BSC with the DEA method in industrial companies (Kádárová et al. 2015). Jin et al. (2015) evaluate the effects of M\&A on acquirers' financial performance. However, company performance is one of the current, but not uniformly comprehended topics in the literature, both regarding the definition of "performance" and its measurement (Žižka et al. 2016).

MNCs as foreign investors are at the centre of a constant debate about their benefits. "The main dynamic in the post-war growth of the MNC has been a structural shift in favour of technology-based goods, which has significantly increased investment in R\&D” (Buckley 2009).

"Over the last two decades, Slovakia has undergone a radical transformation with a dominant orientation to Western Europe. Its open character is testified by the fact that total imports from other EU countries have ranged between $67.6 \%$ and $73 \%$ and total exports to the EU amounted to $85.2 \%$ - 86.8\% between 2004 and 2008" (Rybár 2011). It is reflected in different branches, mostly in the automotive industry. After declining of FDI inflows in Slovakia during the depths of the global financial crisis in 2009, Slovakia has recorded continuous increasing of FDI inflows next 3 years (UNCTAD 2013), despite two facts: FDI inflows in groups of transition and developed economies decreased in 2012 (9\% in transition economies; $32 \%$ in developed economies) and the European Union alone accounted for almost two-thirds of the global FDI decline (UNCTAD 2013).

Several studies and analyses were dedicated to FDI issues in CEE countries (Gauselmann et al. 2011; Ferenčíková, Dudáš 2005; Zajac, Baláž 2007; Dudáš, Lukáč 2014). Study of FDI in the countries of the Visegrad Four (V4) found evidence that FDI has increased labour productivity (Barrell, Holland 2000). Pavlínek and Smith (1998) in their research deal with FDI in the Czech and Slovak Republics. Pavlínek (2002) discussed advantages of foreign ownership for Czech enterprises. Rugraff (2008) focused on the efficiency of the FDI policies in CEE countries of FDI (the spillover effects of FDI). 
Research concerning the FDI determinants and effects especially in Slovakia is limited. The positive effect of FDI on the economic growth is an accepted fact in CEE countries (Ferenčíková, Dudáš 2005). Dow and Ferenčíková (2010) directed their research to the specific FDI issues to Slovakia. An impact of FDI on Slovak economy also analyzed Hošková (2001), indirect effects of FDI commonly referred to as spillovers and its potential in Slovakia defined Fifeková (2008). Quantification of the effects in Slovakia based on the theory of Dunning (1993), where defined that countries in implementing of FDI went through five developmental stages and described potential inward and outward FDI effects in certain phases, published Merková, Rajnoha and Novák (2012). The positive impact of FDI in Slovakia was demonstrated in past research with the main objective to identify significant quantitative and qualitative effects of FDI; findings published Merková, Rajnoha and Novák (2012). The research was aimed at presenting the dependence in the period 1999-2008 and demonstrated significant dependence between FDI stocks and GDP growth of Slovakia. Zajac and Baláž (2007) state, that "Slovakia became a dual economy. Branch-plants of multinational companies benefited from technology diffusion and accounted for high productivity levels. Domestic companies generated low demand on innovative solutions and competed with low costs of production" (Zajac, Baláž 2007). Horta et al. (2016) were demonstrated the impact of internationalisation and diversification strategies on the performance of construction industry companies. The results obtained can guide the design of strategies to pursue company growth and achieve competitive advantage (Horta et al. 2016).

However, effects of FDI and performance of MNCs in different countries may be influenced in opposite direction. A study in selected EU countries (Novotný 2008) states that the rate of return on FDI in the country is higher with the lower effective corporate tax rate. MNC can transmit profit before tax from one country to another through the transfer pricing (Breinek 2005). Transactions of transfer pricing are motivated by trying to minimize tax liability of MNC as a whole, in particular by artificially shifting profits to countries with the lowest tax burden (Pim et al. 2008). Different tax rates and legislation applied worldwide for the taxation of MNCs are the main causes of global economic imbalances and suboptimal allocation of resources (Simmons 2006). Transfer pricing worldwide further gains its importance in the current period, in particular in connection with the growth of globalization and the ongoing financial and economic crisis. Specifically, in Slovakia should be growing interest in such matters is directly proportional to the increasing share of foreign capital, the growth of FDI and increasing number of MNCs. As stated in a recent study Karkinsky and Riedel (2012), intangible assets such as patents and licenses play in the modern economy of MNCs an important part of the value of their assets. MNCs are motivated to place their patents to subsidiaries in countries with low tax rates to optimise their tax (Karkinsky, Riedel 2012).

\section{Material and methods}

\subsection{Research questionnaire and sample}

Data about the primary database of 1,457 enterprises from various industries of the Slovak Republic we received from the information of several industry associations and those we have subsequently supplemented by other companies by the extensive online survey. We asked 
businesses to participate in the research, and our questionnaire was distributed in two consecutive rounds. First, via e-mail (time for completion was two months, low latency - there were completed only 45 research questionnaires). Subsequently, we have therefore used in the second round the form of telephone and the most common form of a face-to-face interview (time for completion was next two months, there were filled other 119 research questionnaires). After these two consecutive rounds, the questionnaires were correctly completed by 164 enterprises in the end, what means $11.26 \%$ response rate.

The data set consisted of all the surveyed firms (164 enterprises), out of which we created sets specifically aimed at firms from the industries of wood processing, engineering and automotive industry. A separate set containing all the enterprises from the three industries was also studied. The final two sets are defined by their core business (focus). The set 6 includes production firms and set 7 includes firms of trade and services. Table 1 presents the data from the research sets.

Table 1. Basic data on the data sets analyzed (source: own)

\begin{tabular}{|c|l|c|}
\hline Set & \multicolumn{1}{|c|}{ The industry focus } & Totals \\
\hline 1 & All industries & $164 \mathrm{firms}$ \\
\hline 2 & Wood Processing & $34 \mathrm{firms}$ \\
\hline 3 & Mechanical engineering & $30 \mathrm{firms}$ \\
\hline 4 & Automotive & $16 \mathrm{firms}$ \\
\hline 5 & Selected industries (Wood processing, Engineering, Automotive) & $80 \mathrm{firms}$ \\
\hline 6 & Manufacturing & $106 \mathrm{firms}$ \\
\hline 7 & Trade and Services & $58 \mathrm{firms}$ \\
\hline
\end{tabular}

We consider the size of the research sample as being sufficiently representative, whereas it compares favourably with several other studies. The research conducted in Spain also focused on the relation between the use of SPMS and the quality of strategic planning. The empirical data was acquired from a sample of 349 middle and large companies (Gimbert et al. 2010). We must emphasize, however, that Spain is a country more times greater and the total number of enterprises operating there is thus substantially higher than in Slovakia. Pangarkar and Lim (2003) focused on the key determinants of the performance levels attained by FDI undertaken by Singapore firms, based on research sample of 128 responses. Next study assessed the determinants and performance consequences, using sample from over 220 SinoJapanese joint ventures in China (Isobe et al. 2000). This study, published in the Academy of Management Journal, what is ranked among the top five most influential and frequently cited management journals worldwide, had the response rate of $14.4 \%$. Based on the above and taking into account the quantitative and qualitative aspect of our research, we consider the sample size to be relevant.

The business performance measured by ROE indicator was key sorting parameter. Companies were initially analysed by distribution according to performance achievement within six performance groups (the group from 0 to 5; group 0 - the worst performance with negative ROE, group 5 - the best performance with ROE above 10\%). Few similar studies apply the ROE indicator. Liu and Anbumozhi (2009) presented the economic performance of 
companies in China by using the ROE indicator. Rothaermel (2001), studying strategic alliances, also used the ROE for expressing the firm performance. Urquía Grande et al. (2011), analysing performance measures in Spanish small and medium enterprises, and also Dehaene, De Vuyst and Ooghe (2001) studying the performance of 122 Belgium companies, focused on profitability indicators ROE and ROA.

Using of scale rather than a particular value of ROE was used because of the sensitivity of the issue. The sufficient number of scales (6) will allow the variability of classifying businesses into different performance categories. In the case of low frequencies, we narrowed the six categories for the following three following groups:

- Inefficient firms (ROE < 0, ROE from $0 \%$ to $2 \%$ ).

- Average performance firms (ROE from $2 \%$ to $7 \%$ ).

- High-performance firms (ROE over 7\%).

\subsection{Statistical methods used in the research}

Data from the research sample were processed and statistical evaluated by chosen methods, we applied the chi-squared test. The research consists of qualitative - nominal variables; their relationship cannot adequately describe the correlation and regression analysis. Pearson's chi-squared test $(\chi 2)$ we applied to sets of categorical data. By Pearson's chi-squared test of independence we assessed whether observations on two variables, expressed in a contingency table, are independent of each other. Results of the statistical procedure were evaluated by reference to the chi-squared distribution. We calculated the chi-squared test statistic $(\chi 2)$, which resembles a normalized sum of squared deviations between observed and theoretical frequencies. Then we made a decision that the observed frequency distribution is the same as the particular theoretical distribution or there is difference between the distributions.

Results of chi-squared tests describe selected statistics: Pearson's chi-square and significance p-value „p“, Maximum-Likelihood chi-square and p-value, Pearson's contingency coefficient (CC), Adjusted contingency coefficient (Adj. CC) and degrees of freedom (df). The Chi-square test becomes increasingly significant when the observations deviate further from the expected pattern. Further information on this issue refers Pearson (1904); Everitt (1977); Kendall and Stuart (1979) or Panik (2005). Assumptions for the chi-squared test are random sample, a sample with a sufficiently large size, adequate expected cell frequencies, and independence of the observations. The $2 \times 2$ tables would be the value of the expected frequency of each cell being in a table greater than 5. For larger tables, compliance of this condition is often problematic. According to Finkelstein and Levin (2001) "for tables larger than 2x2 it is recommended to have at least $80 \%$ of the expected frequency of greater than 5 or not the expected frequency of less than 1 in more than $10 \%$ of cases". The research sample complies with the above assumptions and we consider the Pearson's chi-squared test of independence as a suitable testing method in our research.

We formulated the basic (null) hypothesis $\mathrm{H}_{0}, \mathrm{H}_{1}$ alternative hypothesis and the significance level $\alpha(\alpha=0.05)$ for statistical testing hypotheses. The aim was to try to challenge the hypothesis $\mathrm{H}_{0}$. Null hypothesis $-\mathrm{H}_{0}$ : There is no relationship between selected variables and performance. Alternative hypothesis $-\mathrm{H}_{1}$ : There is a relationship between selected variables and performance. 


\section{Research findings}

In our research, we focused on finding the associations, context among confirmed hypotheses and reasons of significant differences between foreign and domestic firms regarding of their business performance. For each relation, we have present the results of statistics ( $\mathrm{p}$-value $<0.05$ ). Just from the results of residuals we can demonstrate relevant findings presented below.

\subsection{Dependence between foreign ownership and business performance}

From the descriptive statistics of variable business performance (categorised according to the ROE indicator into six groups), presented on Figure 1 shows the mean 2.06, companies in average create positive, but relatively low Return on Equity in the range of $2-4 \%$ in Slovakia. Median is at level 2. Modus, the maximum frequency is represented in the second group with a performance at the level of $0-2 \%$ ROE, which includes $47(29 \%)$ of the total sample of enterprises.

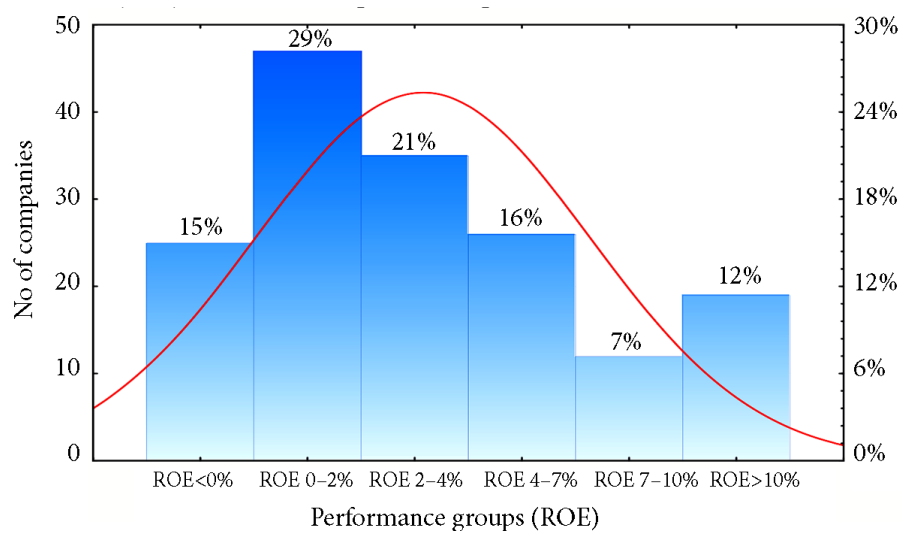

Figure 1. Histogram: business performance - ROE (source: own)

We assumed that some specific parameters, for example, industrial area, size of the company or the legal form could influence the performance of businesses in the sample. We analysed certain specific parameters from the questionnaire with the aim to detect if they are significantly linked with business performance. Results of statistical testing (Table 2), considering $p$-value $p>0.05$ in each relation, did not demonstrate the impact of these parameters on business performance.

The starting point of the research was to find out the difference in performance of firms with purely domestic capital compared to companies with foreign participation (partial or full foreign ownership). The analysis presented in Table 3 means statistically very significant dependence ( $p$-value $<0.001$ ) with Adj. CC 0.40. From the values of residues (Table 4), we show that firms with purely domestic capital typically merit in group 1 (very low ROE in the range of $0-2 \%$ ), enterprises with foreign participation participate in better performance groups, most typically with ROE above $10 \%$. These results demonstrate a statistically significant impact of foreign capital in better business performance, and there is confirmed the first research hypothesis. 
Table 2. Contingency: specific parameters vs. business performance - statistics (source: own)

\begin{tabular}{|l|c|c|c|c|c|}
\hline $\begin{array}{c}\text { Business } \\
\text { Performance vs. } \\
\text { specific parameters }\end{array}$ & Counts & $\begin{array}{c}\text { Pearson's } \\
\text { chi-square }\end{array}$ & df & p & $\begin{array}{c}\text { Contingency } \\
\text { coefficient } \\
\text { (CC) }\end{array}$ \\
\hline Industry & 164 & 19.04715 & 15 & 0.2116 & 0.32 \\
\hline Region of country & 164 & 34.98657 & 35 & 0.4746 & 0.42 \\
\hline Legal form & 164 & 17.02000 & 15 & 0.3177 & 0.31 \\
\hline Age of the company & 164 & 13.84254 & 15 & 0.5375 & 0.28 \\
\hline Size of the company & 164 & 20.04812 & 15 & 0.1701 & 0.33 \\
\hline
\end{tabular}

Table 3. Contingency: foreign ownership $\times$ performance - statistics (source: own)

\begin{tabular}{|c|c|c|c|c|c|c|c|c|c|}
\hline \multirow{2}{*}{$\begin{array}{c}\text { Foreign } \\
\text { investment } \\
\times \text { Perfor- } \\
\text { mance } \\
\text { (Statistic) }\end{array}$} & \multirow[b]{2}{*}{ Counts } & \multicolumn{3}{|c|}{ Pearson's chi-square test } & \multicolumn{3}{|c|}{ M-L Chi-square test } & \multirow{2}{*}{$\begin{array}{l}\text { Contin- } \\
\text { gency } \\
\text { coefficient } \\
\text { (CC) }\end{array}$} & \multirow{2}{*}{ 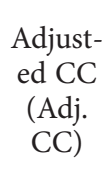 } \\
\hline & & $\begin{array}{l}\text { chi- } \\
\text { square }\end{array}$ & df & $\mathrm{p}$ & $\begin{array}{l}\text { chi- } \\
\text { square }\end{array}$ & $\mathrm{df}$ & $\mathrm{p}$ & & \\
\hline & 164 & 19.205 & 5 & 0.00176 & 21.316 & 5 & 0.00071 & 0.32 & 0.40 \\
\hline
\end{tabular}

Table 4. Contingency: foreign ownership $\times$ performance - frequencies (source: own)

\begin{tabular}{|l|c|c|c|c|c|c|c|c|}
\hline $\begin{array}{c}\text { Foreign } \\
\text { investment } \\
\times \text { Perfor- } \\
\text { mance }\end{array}$ & $\begin{array}{c}\text { Group 0 } \\
\text { ROE } 0\end{array}$ & $\begin{array}{c}\text { Group 1 } \\
\text { ROE: } \\
0-2 \%\end{array}$ & $\begin{array}{c}\text { Group 2 } \\
\text { ROE: } \\
2-4 \%\end{array}$ & $\begin{array}{c}\text { Group 3 } \\
\text { ROE: } \\
4-7 \%\end{array}$ & $\begin{array}{c}\text { Group 4 } \\
\text { ROE: } \\
7-10 \%\end{array}$ & $\begin{array}{c}\text { Group 5 } \\
\text { ROE }> \\
10 \%\end{array}$ & $\begin{array}{r}\text { Row } \\
\text { Totals }\end{array}$ \\
\hline \multicolumn{7}{|c|}{ Frequencies (Observed) } \\
\hline $\begin{array}{l}\text { Domestic } \\
\text { ownership }\end{array}$ & 18 & 44 & 26 & 16 & 6 & 10 & 120 \\
\hline $\begin{array}{l}\text { Foreign } \\
\text { ownership }\end{array}$ & 7 & 3 & 9 & 10 & 6 & 9 & 44 \\
\hline Totals & 25 & 47 & 35 & 26 & 12 & 19 & 164 \\
\hline $\begin{array}{l}\text { Domestic } \\
\text { ownership }\end{array}$ & 18.292 & 34.390 & 25.609 & 19.024 & 8.7804 & 13.902 & 120.00 \\
\hline $\begin{array}{l}\text { Foreign } \\
\text { ownership }\end{array}$ & 6.7073 & 12.609 & 9.3902 & 6.9756 & 3.2195 & 5.098 & 44.00 \\
\hline Totals & 25.000 & 47.000 & 35.000 & 26.000 & 12.000 & 19.000 & 164.00 \\
\hline \multicolumn{7}{|c|}{ Frequencies (Residual) } \\
\hline $\begin{array}{l}\text { Domestic } \\
\text { ownership }\end{array}$ & -0.2926 & $\mathbf{9 . 6 0 9 7}$ & $\mathbf{0 . 3 9 0 2}$ & -3.0243 & -2.7804 & -3.9024 & 0.00 \\
\hline $\begin{array}{l}\text { Foreign } \\
\text { ownership }\end{array}$ & 0.2926 & -9.6097 & -0.3902 & $\mathbf{3 . 0 2 4 3}$ & $\mathbf{2 . 7 8 0 4}$ & 3.9024 & 0.00 \\
\hline Totals & 0.0000 & 0.0000 & 0.0000 & 0.0000 & 0.0000 & 0.0000 & 0.00 \\
\hline
\end{tabular}




\subsection{Performance of German capital invested in Slovakia}

In the research of dependence between the origin of capital and business performance we used optimal binning of classes in variable "origin of capital". The research sample consisted of 17 various answers, and we created four classes. Countries were sorted according to most counts: 120 firms of domestic origin, 27 firms in the group of other foreign origins (21 firms of 15 concrete foreign countries and six firms from the unnamed foreign country), ten firms from Germany and seven from the Czech Republic. The analysis in Table 5 presents statistically very significant dependence ( $\mathrm{p}$-value $<0.001$ ) and Adjusted contingency coefficient (Adj. CC) 0.50 means strong correlation. So, it is important if firms hold foreign capital, but more important is from which foreign country. However, for testing of this hypothesis, despite the binning of classes, did not fulfil the expected counts condition and the credibility of the obtained results may not be entirely relevant. We are aware of the unfulfilled condition; nevertheless, the results we have interpreted. Residual frequencies (Table 6) signify the best and stable performance in firms with German capital (performance group 3, 4 and 5) and this result could confirm the second hypothesis. For the research class of other foreign countries are positive residuals in performance group 0,2 and 5, there is diverse, unreliable performance and we cannot determine the typical results. The success and higher ROE indicator of these firms are possible as well as the negative or low ROE.

Table 5. Contingency: origin of capital $\times$ performance - statistics (source: own)

\begin{tabular}{|c|c|c|c|c|c|c|c|c|c|}
\hline \multirow{2}{*}{$\begin{array}{c}\text { Origin of } \\
\text { capital } \times \\
\text { Perfor- } \\
\text { mance } \\
\text { (Statistic) }\end{array}$} & \multirow[b]{2}{*}{ Counts } & \multicolumn{3}{|c|}{ Pearson's chi-square test } & \multicolumn{3}{|c|}{ M-L Chi-square test } & \multirow{2}{*}{$\begin{array}{l}\text { Contin- } \\
\text { gency } \\
\text { coef- } \\
\text { ficient } \\
\text { (CC) }\end{array}$} & \multirow{2}{*}{$\begin{array}{l}\text { Adjust- } \\
\text { ed CC } \\
\text { (Adj. } \\
\text { CC) }\end{array}$} \\
\hline & & $\begin{array}{l}\text { chi- } \\
\text { square }\end{array}$ & $\mathrm{df}$ & $\mathrm{p}$ & $\begin{array}{l}\text { chi- } \\
\text { square }\end{array}$ & df & $\mathrm{p}$ & & \\
\hline & 164 & 39.860 & 15 & 0.00048 & 40.510 & 15 & 0.00038 & 0.442 & 0.50 \\
\hline
\end{tabular}

Table 6. Contingency: origin of capital x performance - frequencies (source: own)

\begin{tabular}{|l|c|c|c|c|c|c|c|}
\hline $\begin{array}{c}\text { Origin of capital } \\
\text { Performance }\end{array}$ & $\begin{array}{c}\text { Group 0 } \\
\text { ROE }<0\end{array}$ & $\begin{array}{c}\text { Group 1 } \\
\text { ROE: } \\
0-2 \%\end{array}$ & $\begin{array}{c}\text { Group 2 } \\
\text { ROE: } \\
2-4 \%\end{array}$ & $\begin{array}{c}\text { Group 3 } \\
\text { ROE: } \\
4-7 \%\end{array}$ & $\begin{array}{c}\text { Group 4 } \\
\text { ROE: } \\
7-10 \%\end{array}$ & $\begin{array}{c}\text { Group 5 } \\
\text { ROE } \\
>10 \%\end{array}$ & $\begin{array}{c}\text { Row } \\
\text { Totals }\end{array}$ \\
\hline Observed Frequencies \\
\hline Domestic origin & 18 & 44 & 26 & 16 & 6 & 10 & 120 \\
\hline Other foreign origins & 6 & 2 & 7 & 4 & 1 & 7 & 27 \\
\hline Germany & 1 & 1 & 0 & 3 & 3 & 2 & 10 \\
\hline Czech Republic & 0 & 0 & 2 & 3 & 2 & 0 & 7 \\
\hline Totals & 25 & 47 & 35 & 26 & 12 & 19 & 164 \\
\hline \multicolumn{7}{|c|}{ Expected Frequencies } \\
\hline Domestic origin & 18.2927 & 34.3902 & 25.6098 & 19.0244 & 8.7805 & 13.9024 & 120.000 \\
\hline Other foreign origins & 4.1159 & 7.7378 & 5.7622 & 4.2805 & 1.9756 & 3.1281 & 27.000 \\
\hline Germany & 1.5244 & 2.8659 & 2.1342 & 1.5854 & 0.7317 & 1.1585 & 10.000 \\
\hline Czech Republic & 1.0671 & 2.0061 & 1.4939 & 1.1098 & 0.5122 & 0.8110 & 7.000 \\
\hline
\end{tabular}


End of Table 6

\begin{tabular}{|l|c|c|c|c|c|c|c|}
\hline $\begin{array}{c}\text { Origin of capital } \times \\
\text { Performance }\end{array}$ & $\begin{array}{c}\text { Group 0 } \\
\text { ROE }<0\end{array}$ & $\begin{array}{c}\text { Group 1 } \\
\text { ROE: } \\
0-2 \%\end{array}$ & $\begin{array}{c}\text { Group 2 } \\
\text { ROE: } \\
2-4 \%\end{array}$ & $\begin{array}{c}\text { Group 3 } \\
\text { ROE: } \\
4-7 \%\end{array}$ & $\begin{array}{c}\text { Group 4 } \\
\text { ROE: } \\
7-10 \%\end{array}$ & $\begin{array}{c}\text { Group 5 } \\
\text { ROE } \\
>10 \%\end{array}$ & $\begin{array}{c}\text { Row } \\
\text { Totals }\end{array}$ \\
\hline Totals & 25.0000 & 47.0000 & 35.0000 & 26.0000 & 12.0000 & 19.0000 & 164.000 \\
\hline \multicolumn{7}{|c|}{ Residual Frequencies } \\
\hline Domestic origin & -0.2927 & 9.6098 & 0.3902 & -3.0244 & -2.7805 & -3.9024 & 0.00 \\
\hline Other foreign origins & 1.8842 & -5.7378 & 1.2378 & -0.2805 & -0.9756 & 3.8720 & 0.00 \\
\hline Germany & -0.5244 & -1.8659 & -2.1342 & 1.4146 & 2.2683 & 0.8415 & 0.00 \\
\hline Czech Republic & -1.0671 & -2.0061 & 0.5061 & 1.8902 & 1.4878 & -0.8190 & 0.00 \\
\hline Totals & 0.0000 & 0.0000 & 0.0000 & 0.0000 & 0.0000 & 0.0000 & 0.00 \\
\hline
\end{tabular}

\subsection{Intangibles and research \& development in foreign-owned firms}

Focusing on investment activity, we asked in the questionnaire which kind of investment is crucial in companies and were founding an association with domestic or foreign ownership (Table 7). There is a statistically significant relationship in two kinds from nine possibilities of investment, what confirms the third hypothesis. Crucial investments are:

- Investments in Intangible assets: know-how, innovations, brands, reputations, other knowledge capital, patents, licenses, rights, software.

- Investments in Research and Development (R\&D).

Residual frequencies demonstrate in both cases (Table 8 and Table 9), that occurrence of these kinds of crucial investment is typical only for foreign firms, while these investments are not considered as crucial in Slovak firms.

Table 7. Contingency: foreign ownership $\times$ crucial investment - statistics (source: own)

\begin{tabular}{|l|c|c|c|c|c|c|c|}
\hline $\begin{array}{l}\text { Foreign ownership } \times \\
\text { Crucial investment } \\
\text { (Statistic) }\end{array}$ & Counts & $\begin{array}{c}\text { Positive } \\
\text { answers }\end{array}$ & $\begin{array}{c}\text { Pearson's } \\
\text { chi- } \\
\text { square }\end{array}$ & $\mathrm{df}$ & $\mathrm{p}$ & $\begin{array}{c}\text { Contin- } \\
\text { gency } \\
\text { coefficient } \\
\text { (CC) }\end{array}$ & $\begin{array}{c}\text { Adjusted } \\
\text { CC } \\
\text { (Adj. CC) }\end{array}$ \\
\hline $\begin{array}{l}\text { Technology, machin- } \\
\text { ery, equipment }\end{array}$ & 164 & 128 & 2.426 & 1 & 0.119 & 0.121 & 0.17 \\
\hline Intangibles & $\mathbf{1 6 4}$ & $\mathbf{5 5}$ & $\mathbf{3 . 8 3 1}$ & $\mathbf{1}$ & $\mathbf{0 . 0 5 0}$ & $\mathbf{0 . 1 5 1}$ & $\mathbf{0 . 2 1}$ \\
\hline $\begin{array}{l}\text { Construction } \\
\text { investments }\end{array}$ & 164 & 51 & 0.676 & 1 & 0.795 & 0.203 & 0.29 \\
\hline $\begin{array}{l}\text { Training and staff } \\
\text { development }\end{array}$ & 164 & 46 & 1.088 & 1 & 0.297 & 0.812 & 1.15 \\
\hline $\begin{array}{l}\text { Research and } \\
\text { development }\end{array}$ & $\mathbf{1 6 4}$ & $\mathbf{1 9}$ & $\mathbf{7 . 2 8 7}$ & $\mathbf{1}$ & $\mathbf{0 . 0 0 6}$ & $\mathbf{0 . 2 0 6}$ & $\mathbf{0 . 2 9}$ \\
\hline $\begin{array}{l}\text { Financial } \\
\text { investments }\end{array}$ & 164 & 17 & 0.105 & 1 & 0.746 & 0.025 & 0.04 \\
\hline Vehicles & 164 & 2 & 0.742 & 1 & 0.388 & 0.067 & 0.09 \\
\hline Quality assurance & 164 & 2 & 0.553 & 1 & 0.456 & 0.058 & 0.08 \\
\hline Marketing & 164 & 1 & - & - & - & - & - \\
\hline
\end{tabular}


Table 8. Contingency: foreign ownership $\times$ intangibles - frequencies (source: own)

\begin{tabular}{|l|c|c|c|}
\hline $\begin{array}{c}\text { Crucial Investment: } \\
\text { Intangible assets }\end{array}$ & $\begin{array}{c}\text { Intangibles are not } \\
\text { crucial investment }\end{array}$ & $\begin{array}{c}\text { Intangibles are } \\
\text { crucial investment }\end{array}$ & Row Totals \\
\hline \multicolumn{4}{|c|}{ Observed Frequencies } \\
\hline Domestic ownership & 85 & 35 & 120 \\
\hline Foreign ownership & 24 & 20 & 44 \\
\hline Totals & 109 & 55 & 164 \\
\hline \multicolumn{5}{|c|}{ Expected Frequencies } \\
\hline Domestic ownership & 79.7561 & 40.2439 & 120.0000 \\
\hline Foreign ownership & 29.2439 & 14.7561 & 164.0000 \\
\hline Totals & 109.0000 & 55.0000 & 0.00000 \\
\hline \multicolumn{5}{|c|}{ Residual Frequencies } \\
\hline Domestic ownership & $\mathbf{5 . 2 4 3 9 0}$ & -5.24390 & 0.00000 \\
\hline Foreign ownership & -5.24390 & $\mathbf{5 . 2 4 3 9 0}$ & 0.00 \\
\hline Totals & 0.00 & 0.00 & \\
\hline
\end{tabular}

Table 9. Contingency: foreign ownership $\times$ research and development - frequencies (source: own)

\begin{tabular}{|l|c|c|c|}
\hline $\begin{array}{c}\text { Crucial Investment: } \\
\text { Intangible assets }\end{array}$ & $\begin{array}{c}\text { R\&D is not crucial } \\
\text { investment }\end{array}$ & $\begin{array}{c}\text { R\&D is crucial invest- } \\
\text { ment }\end{array}$ & Row Totals \\
\hline \multicolumn{5}{|c|}{ Observed Frequencies } \\
\hline Domestic ownership & 111 & 9 & 120 \\
\hline Foreign ownership & 34 & 10 & 164 \\
\hline Totals & 145 & 19 & 120.0000 \\
\hline \multicolumn{5}{|c|}{ Expected Frequencies } \\
\hline Domestic ownership & 106.0976 & 13.9024 & 44.0000 \\
\hline Foreign ownership & 38.9024 & 5.0976 & 164.0000 \\
\hline Totals & 145.0000 & 19.0000 & 0.00000 \\
\hline \multicolumn{5}{|c|}{ Residual Frequencies } \\
\hline Domestic ownership & $\mathbf{4 . 9 0 2 4 4}$ & -4.90244 & 0.00000 \\
\hline Foreign ownership & -4.90244 & $\mathbf{4 . 9 0 2 4 4}$ & 0.00 \\
\hline Totals & 0.00 & 0.00 & \\
\hline
\end{tabular}

\subsection{No relationship between crucial investment and better performance}

When in the third research hypothesis we have shown that for foreign-owned firms are typical some kinds of investment, we tried to prove that mentioned crucial investment results in a higher business performance. Researching presented in Table 8, we conducted on the entire sample ( $\mathrm{N}=164$ firms) as well as in separate groups of foreign firms $(\mathrm{N}=44)$ and domestic firms $(\mathrm{N}=120)$. If this dependence was confirmed (globally or just for foreign companies), we could give to Slovak companies the clear message that intangible and R\&D investments affect their performance. 
Table 10. Contingency: crucial investment $\times$ performance - statistics (source: own)

\begin{tabular}{|l|c|c|c|c|c|c|}
\hline $\begin{array}{c}\text { Crucial in- } \\
\text { vestment } \times \\
\text { Performance } \\
\text { (Statistic) }\end{array}$ & Counts & $\begin{array}{c}\text { Pearson's } \\
\text { chi-square }\end{array}$ & $\mathrm{df}$ & $\mathrm{p}$ & $\begin{array}{c}\text { Contin- } \\
\text { gency coef- } \\
\text { ficient (CC) }\end{array}$ & $\begin{array}{c}\text { Adjusted } \\
\text { CC (Adj. } \\
\text { CC) }\end{array}$ \\
\hline $\begin{array}{l}\text { Intangibles (all } \\
\text { firms) }\end{array}$ & 164 & 5.997 & 5 & 0.307 & 0.188 & 0.232 \\
\hline R\&D (all firms) & 164 & 1.662 & 5 & 0.894 & 0.100 & 0.123 \\
\hline $\begin{array}{l}\text { Intangibles } \\
\text { (foreign firms) }\end{array}$ & 44 & 1.490 & 5 & 0.914 & 0.181 & 0.223 \\
\hline $\begin{array}{l}\text { R\&D (foreign } \\
\text { firms) }\end{array}$ & 44 & 3.120 & 5 & 0.682 & 0.257 & 0.317 \\
\hline $\begin{array}{l}\text { Intangibles } \\
\text { (domestic } \\
\text { firms) }\end{array}$ & $\mathbf{1 2 0}$ & $\mathbf{1 5 . 0 1 0}$ & $\mathbf{5}$ & $\mathbf{0 . 0 1 0}$ & $\mathbf{0 . 3 3 3}$ & $\mathbf{0 . 4 1 1}$ \\
\hline $\begin{array}{l}\text { R\&D (domestic } \\
\text { firms) }\end{array}$ & 120 & 2.380 & 5 & 0.794 & 0.139 & 0.171 \\
\hline
\end{tabular}

Table 11. Contingency: intangibles in domestic firms $\times$ performance - frequencies (source: own)

\begin{tabular}{|l|c|c|c|c|c|c|c|}
\hline $\begin{array}{c}\text { Intangibles in } \\
\text { domestic firms } \times \\
\text { Performance }\end{array}$ & $\begin{array}{c}\text { Group 0 } \\
\text { ROE }<0\end{array}$ & $\begin{array}{c}\text { Group 1 } \\
\text { ROE: } \\
0-2 \%\end{array}$ & $\begin{array}{c}\text { Group 2 } \\
\text { ROE: } \\
2-4 \%\end{array}$ & $\begin{array}{c}\text { Group 3 } \\
\text { ROE: } \\
4-7 \%\end{array}$ & $\begin{array}{c}\text { Group 4 } \\
\text { ROE: } \\
7-10 \%\end{array}$ & $\begin{array}{c}\text { Group 5 } \\
\text { ROE } \\
>10 \%\end{array}$ & $\begin{array}{c}\text { Row } \\
\text { Totals }\end{array}$ \\
\hline \multicolumn{7}{|c|}{ Observed Frequencies } \\
\hline Without intangibles & 8 & 33 & 15 & 14 & 6 & 9 & 85 \\
\hline $\begin{array}{l}\text { Intangible } \\
\text { investments }\end{array}$ & 10 & 11 & 11 & 2 & 0 & 1 & 35 \\
\hline Totals & 18 & 44 & 26 & 16 & 6 & 10 & 120 \\
\hline \multicolumn{7}{|c|}{ Expected Frequencies } \\
\hline Without intangibles & 12.750 & 31.167 & 18.417 & 11.333 & 4.250 & 7.083 & 85.00 \\
\hline $\begin{array}{l}\text { Intangible } \\
\text { investments }\end{array}$ & 5.250 & 12.833 & 7.583 & 4.667 & 1.7500 & 2.917 & 35.00 \\
\hline Totals & 18.000 & 44.000 & 26.000 & 16.000 & 6.0000 & 10.000 & 120.00 \\
\hline \multicolumn{7}{|c|}{ Residual Frequencies } \\
\hline Without intangibles & -4.750 & 1.833 & -3.417 & $\mathbf{2 . 6 6 7}$ & $\mathbf{1 . 7 5 0}$ & $\mathbf{1 . 9 1 7}$ & 0.00 \\
\hline $\begin{array}{l}\text { Intangible } \\
\text { investments }\end{array}$ & 4.750 & -1.833 & 3.417 & -2.667 & -1.750 & -1.917 & 0.00 \\
\hline Totals & 0.0000 & 0.0000 & 0.0000 & 0.0000 & 0.0000 & 0.0000 & 0.00 \\
\hline
\end{tabular}

In case of foreign ownership, the contingency is not statistically significant. We cannot say if certain investments influence business performance. Efforts to connect to two confirmed research hypotheses (the first: better performance we can connect with foreign-owned firms; the third: foreign firms are interested in intangible and R\&D investments) were not successful, because the fourth hypothesis (better performance is caused just by crucial investments) was not demonstrated considering foreign firms (Table 10). 
Research of dependence in domestic firms between intangibles and performance confirmed that there is statistically significant but moderate correlation ( $\mathrm{p}=0.01$, Adj. CC $=0.41$ ). Moreover, because of unpleasant residual frequencies (Table 11), we can say that domestic firms investing in intangibles reach lower performance than foreign firms.

\subsection{Relations in tested research hypotheses}

Based on the results of statistical analysis we had constructed a model of relations between the research parameters, we visualised our statement to the results of testing hypotheses. Extensive model aimed at foreign-owned firms (Figure 2), consequently also model interesting in domestic Slovak firms (Figure 3).

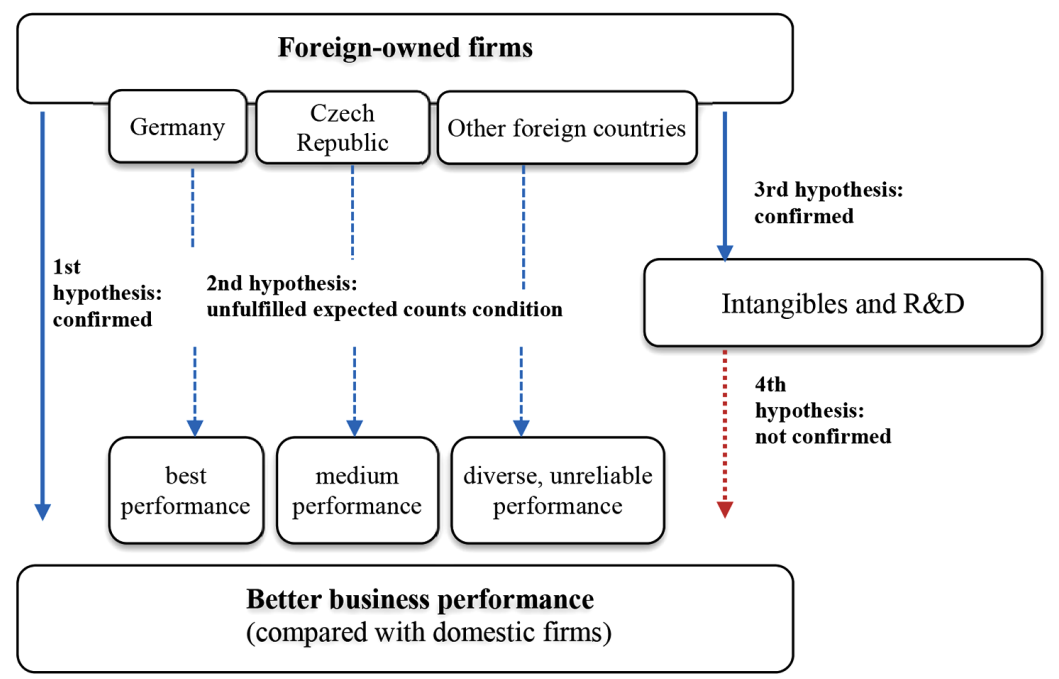

Figure 2. Confirmation of research hypotheses in foreign firms (source: own)

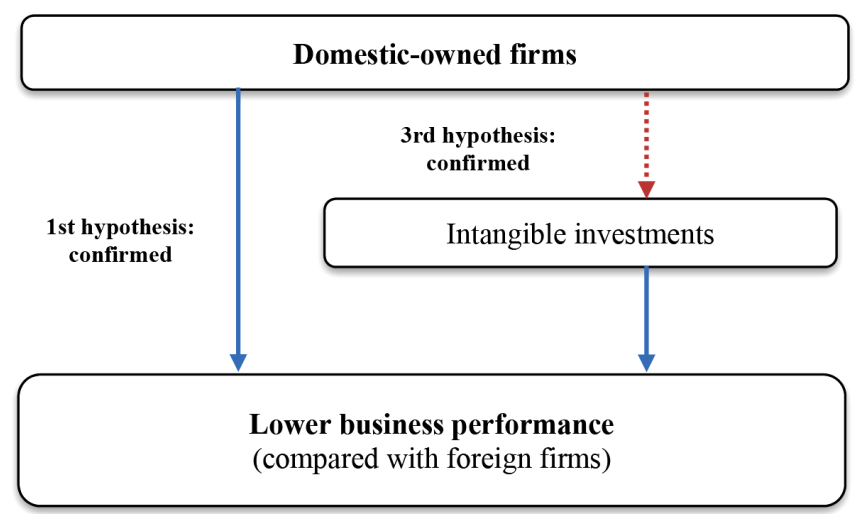

Figure 3. Confirmation of research hypotheses in domestic firms (source: own) 


\section{Discussion}

Results of the research based on statistical evidence as well as models presented above highlighted certain facts and relations and their possible occasions.

As follows from the results of our research, one of the key differences between domestic and foreign companies operating in Slovakia is that foreign investors achieve better business performance by using certain manners in their management. Investments focused in intangibles and $\mathrm{R} \& \mathrm{D}$ are connected with sophisticated production, higher added value and economic growth. Foreign firms profit from advantages, which the host country provides, uses inexpensive raw material resources and particularly the cheap labour force, which is the main comparative advantage of Slovakia. This reality is often criticized as exploitation of workers and natural resources without the positive impact on the economic growth of the country. However, it is important to perceive proved positives, advanced technology in transition country of Slovakia is precisely because of foreign-owned firms. Supported result refutes sceptical views of the FDI opponents, who argue that foreign firms in Slovakia only use outdated tools and procedures without requirements to develop and improve their knowledge base. Local firms could benefit from the entry of multinational corporations (MNCs) thanks, spillovers and improve own business.

Regarding country of origin of foreign capital, it was in our empirical study also uncovered in Slovakia several remarkable facts. Power and success of German capital were proven. Applied business planning, exactly determined goals and ways to achieve them, precisely developed conceptions and methodological procedures. German firms use in strategic management modern, useful and efficient tools, manners, knowledge base, information systems based on business intelligence, controlling with the positive impact on performance. Medium performance (ROE groups 2, 3 and 4) reach firms with the origin of capital from the Czech Republic. This fact is little surprising comparing the result of Slovak firms with lower performance (in performance group 1). Even in recent past, there was a general view that firms of two countries from common state Czechoslovakia reach approximately the same (low) performance level. The current reality in Slovakia is that Czech firms have better performance than domestic firms.

The focus of our research on the type of investment activity has shown that domestic firms do not invest decisively into intangible and research and development activities have shown that domestic firms do not invest crucially to intangibles and R\&D. Similar results also bring the research study presented by Zajac and Baláž (2007). There are several reasons for the absence of these kinds of investment in local firms:

- Lack of capital to invest.

- If they have to choose the investment, seems to be more investment in direct relation to the production - technology, machinery. Mentioned tangible investments often are not as capital intensive as a serious $\mathrm{R} \& \mathrm{D}$. Return on investment to technology begins with its use, in contrast to $\mathrm{R} \& \mathrm{D}$, where benefits come later and are less certain. As for the second group - know-how, innovations, brands, reputations, other knowledge capital, patents, licenses, rights, software - it may be that Slovak enterprises are not considered important, they believe it is not necessary for their business success.

- A typical sign of local firms is indifference and aversion of using new and unfamiliar tools because they do not understand or do not trust those. If the company does 
not trust them, it does not expect possible future effects, especially improving performance. So, the firms use old customary manners without the need of change or innovations.

Less than a quarter of domestic firms from research sample invest crucially to intangibles, and, surprisingly, they proved lower performance than without intangibles. The most significant result in the performance group $0(\mathrm{ROE}<0)$ can have two reasons:

- Slovakia according to UNCTAD is a member of developed countries group, but most rankings, dealing with the business environment or country competitiveness, identify Slovakia to transition countries. Domestic firms are "beginners" in investment activity to intangibles, this start phase is not profitable, and the effect from intangibles will come later;

- Slovak firms invest to intangibles, however, long-term unsuccessfully, and business is not efficient, domestic firms do not know how to invest in the right area. However, as demonstrates analysis in foreign firms, these are not the sure pattern.

The analysis in domestic firms is though less interesting than in foreign ones since intangibles and R\&D are not a crucial investment for this sample.

It was logical to suppose if foreign and - according to the first confirmed hypothesis - the best-performing firms purposely invest in intangibles and $R \& D$, these investments directly result in the better performance. However, intangibles and R\&D are crucial and useful investments in foreign firms, but they do not cause better business performance. So, we consider that the priority of specifically targeted investments is not the increased performance. Foreign firms invest, but for another purpose in given country. The goal of profit pursues a multinational enterprise as a whole, which is not always true for individual members of MNC. One of the major factors that influence the strategic and operational decision of companies is the tax policy of the state, respectively from the perspective of the company it is tax planning. MNC try to optimise profits to achieve savings from localisation of MNC members in different countries of the world with different tax rates according to the principles of transfer pricing. Institute of transfer pricing of corporate outputs provides the valuation of a transaction between related parties on the principles of independent relationship, but on the other hand also allow to optimise profits and the tax burden of those dependents, within certain limits allowed. As describe Bartelsman and Beetsma (2003), relatively small distortion of transfer prices for large cross-border transactions within MNCs is difficult to detect for the tax authorities, especially when there is no comparable external market for similar business transactions and when a large part of their total value is realised in the field of intellectual property. Results of the recent empirical research realised in Slovakia (Rajnoha et al. 2014), where authors considered economic and tax aspects of transfer pricing, showed that even nearly one-third of transactions examined in the selected sample of MNCs operating in Slovakia was based on incorrect transfer pricing method. From this research also followed another significant fact that the crucial part of these incorrectly set transfer prices concerned mainly intangibles and R\&D (Rajnoha et al. 2014). Therefore, the company can optimize their profits because of adhering to the principles of transfer pricing and could also optimize their tax liability by transferring the part of the profit to the country with favourable tax burden and thus artificially reduce its business performance. Alternatively, the methodically incorrect setting of transfer prices may cause long-term losses of the company and therefore the lower total business performance. 
Intangible assets such as patents and licenses constitute in the modern economy of MNCs an important part of the value of their assets and represent a significant portion of tax optimization within the MNCs operating in EU countries. MNCs are motivated to place their patents to subsidiaries in countries with low tax rates to optimize their tax burden within MNC (Karkinsky, Riedel 2012). Therefore, we believe that foreign firms are performing better than domestic Slovak enterprises, but part of the research sample consisting currently of MNCs and their multinational interests caused that our fourth hypothesis has not been statistically proven.

Because of these unusual results, we have focused our further research on the sample consisting of only foreign enterprises $(\mathrm{N}=44)$, which mainly invested in intangible assets and R\&D. By country of origin of capital, we have chosen three groups - Germany (10 counts), Czech Republic (7 counts) and other capital (27 counts). The results are presented in Table 12.

Table 12. Contingency: origin of capital $\times$ crucial investment - statistics (source: own)

\begin{tabular}{|l|c|c|c|c|c|}
\hline $\begin{array}{c}\text { Origin of capital } \\
\times \text { Crucial invest- } \\
\text { ment (Statistic) }\end{array}$ & Counts & $\begin{array}{c}\text { Pearson's } \\
\text { chi-square }\end{array}$ & df & p & $\begin{array}{c}\text { Contingency } \\
\text { coefficient } \\
\text { (CC) }\end{array}$ \\
\hline Intangibles & 44 & 2.266737 & 2 & 0.322 & 0.221 \\
\hline R\&D & 44 & 0.589132 & 2 & 0.745 & 0.115 \\
\hline
\end{tabular}

According to the statistical test, where p-value was more than 0.05 in both analyses concerning intangibles as well as R\&D, did not demonstrate statistically significant contingency. Thus, we cannot prove any differences in investing behaviour in tested countries; it does not appear that Germany would invest in the field of intangibles and R\&D more significantly than the Czech Republic or other countries.

\section{Conclusions}

Several studies were dedicated to FDI issues in CEE countries (Dudáš, Lukáč 2014; Gauselmann et al. 2011; Rybáŕ 2011; Dow, Ferenčíková 2010; Chidlow et al. 2009; Fifeková 2008; Pavlínek 2002; Rugraff 2008; Zajac, Baláž 2007; Fisher et al. 2007; Giroud 2007; Fabry, Zeghni 2006; Ferenčíková, Dudáš 2005; Bevan, Estrin 2004; Beyer 2002; Barrell, Holland 2000).

Based on these macroeconomic studies and also own research, in which we have shown the positive effects of the FDI at the level of macro environment (Merková, Rajnoha and Novák 2012), we then hypothesised certain influence of foreign firms in microeconomics, and we tested if companies with foreign capital are performing better.

Current research has confirmed in the first hypothesis that better business performance is significantly dependent on financing from foreign capital. The best-performing companies (the most typically reaching of ROE above 10\%) are mainly or wholly financed from abroad, and vice versa, for purely domestic firms are a characteristic lower performance with a value of ROE in the range of $0-2 \%$.

The second hypothesis about the best performance of German capital would be confirmed, but there did not fulfil the expected counts condition, and the credibility of the 
obtained results may not be entirely relevant. Nevertheless, concluded results suggest that the country of origin of capital has statistically significant effect in achieving performance.

Consequently, we analysed individual kinds of investment comparing their participation in local and foreign firms. The research of the third hypothesis found out that for the companies with foreign participation is typical focusing in certain investments: intangible assets and area of research and development. Similar findings brings the research study posted by Zajac and Baláž (2007) also Buckley (2009). Although they stated, opposite to our research findings, the different reasons to this behaviour.

The fourth hypothesis, if these crucial investments positively influence the business performance, was not confirmed in a group of foreign firms, so intangibles and R\&D are crucial investments, but they do not directly cause better business performance. The result of statistics could significantly affect the part of the research sample consisting of MNCs and their transactions through transfer pricing as a strategic element in corporate management, aimed to reduce the tax burden effectively influencing the businesses performance just through intangible investments. According to Karkinsky and Riedel, intangible assets in the modern economy of MNCs an important part of the value of their assets and represent a significant portion of tax optimisation within the MNCs operating in EU countries (Karkinsky, Riedel 2012). Similar conclusions were declared also by other researchers (Pim et al. 2008; Novotný 2008; Simmons 2006; Breinek 2005; Bartelsman, Beetsma 2003). Also results of other own empirical research showed that even nearly one-third of transactions examined in the selected sample of MNCs operating in Slovakia was based on incorrect transfer pricing method and the crucial part of these incorrectly set transfer prices concerned mainly intangibles and R\&D (Rajnoha et al. 2014).

The current research is not definitive, but existing results offer relevant and interesting benefits as well as motives for further investigation. We have summarised the findings of extensive empirical research in the following points:

1. Domestic capital and purely domestic enterprises in Slovakia are less powerful than those with foreign capital.

2. Foreign capital in Slovakia achieves higher performance than domestic, and the just German capital is most powerful.

3. Foreign capital has made crucial investments in intangible assets and R\&D contrary to domestic enterprises.

4. Despite the strategic investments of foreign enterprises in intangibles and $R \& D$, those have not effect in their higher performance. One of the reasons may also be purposefully setting of transfer prices in MNCs.

It is also appreciated that relevance of achieved findings is and likely always will be affected by the overall economic development when the research being carried out, furthermore by the size and quality of the research sample, or a parameter that is set in research to assess the overall economic performance of the company. It is possible, also on the basis above, suggest some important guidelines for future research on this issue:

- We are aware that assessing the overall business performance according to the ROE indicator can be distorted; and also due to the results achieved, we will in our further research consider using the indicator ROA (Return on Assets) or EBITDA (Earnings before Interest, Taxes, Depreciation and Amortization). 
- It will be necessary to realise the study in the longer term since it is known that investments in intangible assets and R\&D are considered as strategic investments bringing higher profitability after a certain time. So, in our research, they did not have yet to reflect fully in business performance measured by ROE indicator.

- It is necessary to accurately separate the companies with foreign capital participation from MNCs to gain a clearer picture of the performance in the two distinct groups.

\section{Acknowledgements}

The contribution is the result of VEGA Project No. 1/0255/2016 „The research on the possibility of optimization of process-oriented models of the financial administration management with a focus on transfer pricing and tax harmonization in the terms of EU".

\section{References}

Achim, M. V.; Borlea, S. N.; Mare, C. 2016. Corporate governance and business performance: Evidence for the Romanian economy, Journal of Business Economics and Management 17(3): 458-474. https://doi.org/10.3846/16111699.2013.834841

Barrell, R.; Holland, D. 2000. Foreign direct investment and enterprise restructuring in Central Europe, Economics of Transition 8: 477-504. https://doi.org/10.1111/1468-0351.00052

Bartelsman, E.; Beetsma, R. 2003. Why pay more? Corporate tax avoidance through transfer pricing in OECD countries, Journal of Public Economics 87(9-10): 2225-2252. https://doi.org/10.1016/S0047-2727(02)00018-X

Belás, J.; Gabčová, L. 2016. The relationship among customer satisfaction, loyalty and Financial performance of commercial banks, E+M Ekonomie a Management 19(1): 132-147. https://doi.org/10.15240/tul/001/2016-1-010

Belás, J.; Sopková, G. 2016. A model of entrepreneurial orientation, Transformation in Business \& Economics 15(2B): 630-645.

Bevan, A.; Estrin, S. 2004. The determinants of FDI into European transition economies, Journal of Comparative Economic 32(4): 775-787. https://doi.org/10.1016/j.jce.2004.08.006

Beyer, J. 2002. "Please invest in our country" - how successful were the tax incentives for foreign investment in transition countries?, Communist and Post-Communist Studies 35(2): 191-211. https://doi.org/10.1016/S0967-067X(02)00007-7

Bisbe, J.; Malagueňo, R. 2012. Using strategic performance measurement systems for strategy formulation: Does it work in dynamic environments?, Management Accounting Research 23(4): 296-311. https://doi.org/10.1016/j.mar.2012.05.002

Breinek, P. 2005. Procesy globalizace ve světové ekonomice, Politická ekonomie 53(6): 826-841. https://doi.org/10.18267/j.polek.540

Buckley, P. J. 2009. Internalisation thinking: From the multinational enterprise to the global factory, International Business Review 18(3): 224-235. https://doi.org/10.1016/j.ibusrev.2009.01.006

Chidlow, A.; Salciuviene, L.; Young, S. 2009. Regional determinants of inward FDI distribution in Poland, International Business Review 18(2): 119-133. https://doi.org/10.1016/j.ibusrev.2009.02.004

Czarniewski, S. 2016. Small and medium-sized enterprises in the context of innovation and entrepreneurship in the economy, Polish Journal of Management Studies 13(1): 30-39.

https://doi.org/10.17512/pjms.2016.13.1.03 
Dehaene, A.; De Vuyst, V.; Ooghe, H. 2001. Corporate performance and board structure in Belgian companies, Long Range Planning 34(3): 383-398. https://doi.org/10.1016/S0024-6301(01)00045-0

Dow, D.; Ferenč́ková, S. 2010. More than just national cultural distance: Testing new distance scales on FDI in Slovakia, International Business Review 19(1): 46-58. https://doi.org/10.1016/j.ibusrev.2009.11.001

Dubravská, M.; Mura, L.; Kotulič, R.; Novotný, J. 2015. Internationalization of entrepreneurship - motivating factors: Case study of the Slovak Republic, Acta Polytechnica Hungarica 12(5): 121-133.

Dudáš, T.; Lukáč, M. 2014. Increase in labour productivity in the context of FDI inflows into the automotive industry of Visegrad Group member states, Actual Problems of Economics 162(12): 96-105.

Dunning, J. H. 1993. Trade, location of economic activity and the MNC: A search for an eclectic approach. London: The United Nation Library on Transnational Corporations.

Dunning, J. H. 2000. The eclectic paradigm as an envelope for economic and business theories of MNC activity, International Business Review 9(2): 163-190. https://doi.org/10.1016/S0969-5931(99)00035-9

Everitt, B. S. 1977. The analysis of contingency tables. London: Chapman, Hall. https://doi.org/10.1007/978-1-4899-2927-3

Fabry, N.; Zeghni, S. 2006. How former communist countries of Europe may attract inward foreign direct investment? A matter of institutions, Communist and Post-Communist Studies 39(2): 201-219. https://doi.org/10.1016/j.postcomstud.2006.03.006

Ferenčíková, S.; Dudáš, T. 2005. The impact of foreign direct investment inflows on the economic growth in the New EU member states from Central and Eastern Europe, Ekonomický casopis/ Journal of Economics 53(3): 261-272.

Fifeková, M. 2008. Foreign direct investment and spillover effects [online]. Available from Internet: http:// alternativa.sk/uploads/tx_clanok/Fifekova_RP.pdf

Finkelstein, M. O.; Levin, B. 2001. Statistics for lawyers. New York: Springer.

Fisher, S.; Gould, J. A.; Haughton, T. J. 2007. Slovakia’s Neoliberal turn, Europe-Asia Studies 59(3): 977-998. https://doi.org/10.1080/09668130701489170

Gauselmann, A.; Knell, M.; Stephan, J. 2011. What drives FDI in Central-Eastern Europe? Evidence from the IWH-FDI-Micro database, Post-Communist Economies 23(3): 343-357. https://doi.org/10.1080/14631377.2011.595148

Gimbert, X.; Bisbe, J.; Mendoza, X. 2010. The role of performance measurement systems in strategy formulation processes, Long Range Planning 43(4): 477-497. https://doi.org/10.1016/j.lrp.2010.01.001

Giroud, A. 2007. MNC vertical linkages: The experience of Vietnam after Malaysia, International Business Review 16: 159-176. https://doi.org/10.1016/j.ibusrev.2006.11.003

Horta, I. M.; Kapelko, M.; Lansink, A. O.; Camanho, A. S. 2016. The impact of internationalization and diversification on construction industry performance, International Journal of Strategic Property Management 20(2): 172-183. https://doi.org/10.3846/1648715X.2015.1123201

Hošková, A. 2001. Impact of foreign direct investment in the economy of Slovakia. National Bank of Slovakia, Bratislava [online]. Available from Internet: http://www.nbs.sk/PUBLIK/HOS56.PDF

Isobe, T.; Makino, S.; Montgomery, D. 2000. Resource commitment, entry timing, and market performance of foreign direct investments in emerging economies: The case of Japanese international joint ventures in China, Academy of Management Journal 43(3): 468-484. https://doi.org/10.2307/1556405

Jin, Z.; Xia, B.; Li, V.; Li, H.; Skitmore, M. 2015. Measuring the effects of mergers and acquisitions on the economic performance of real estate developers, International Journal of Strategic Property Management 19(4): 358-367. https://doi.org/10.3846/1648715X.2015.1072858 
Kádárová, J.; Durkáčová, M.; Teplická, K.; Kádár, G. 2015. The proposal of an innovative integrated BSC-DEA model, Procedia Economics and Finance 23: 1503-1508. https://doi.org/10.1016/S2212-5671(15)00375-5

Kalotay, K. 2002. Central and Eastern Europe: Export platform for investors? The Journal of World Investment 3(6): 1037-1059. https://doi.org/10.1163/221190002X00364

Kalotay, K.; Sulstarová, A. 2010. Modelling Russian outward FDI, Journal of International Management 16(2 Special Issue): 131-142. https://doi.org/10.1016/j.intman.2010.03.004

Karkinsky, T.; Riedel, N. 2012. Corporate taxation and the choice of patent location within multinational firms, Journal of International Economics 88(1): 176-185. https://doi.org/10.1016/j.jinteco.2012.04.002

Kendall, M.; Stuart, A. 1979. The advanced theory of statistics. Vol. 2. New York: Hafner.

Ključnikov, A.; Belás, J.; Kozubíková, L.; Paseková, P. 2016. The entrepreneurial perception of SME business environment quality in the Czech Republic, Journal of Competitiveness 8(1): 66-78. https://doi.org/10.7441/joc.2016.01.05

Knápková, A.; Homolka, L.; Pavelková, D. 2014. Utilization of balanced scorecard and the effect of its use on the financial performance of companies in the Czech Republic, E + M Ekonomie a Management 17(2): 146-160. https://doi.org/10.15240/tul/001/2014-2-011

Korauš, A.; Štefko, R.; Dobrovič, J. 2015. Acqusition activity in financial sector, in $12^{\text {th }}$ International Scientific Conference on European Financial Systems 2015. Brno: Masarykova univerzita v Brne, 277-286.

Liu, X.; Anbumozhi, V. 2009. Determinant factors of corporate environmental information disclosure: an empirical study of Chinese listed companies, Journal of Cleaner Production 17(6): 593-600. https://doi.org/10.1016/j.jclepro.2008.10.001

Merková, M.; Rajnoha, R.; Novák, P. 2012. Quantitative and qualitative diagnostic methods for measuring the effects of foreign direct investment of the wood processing industry in the Slovak Republic, Drewno-Wood 55(187): 65-87.

Morgan, R. E.; Strong, C. A. 2003. Business performance and dimensions of strategic orientation, Journal of Business Research 56(3): 163-176. https://doi.org/10.1016/S0148-2963(01)00218-1

Novotný, F. 2008. Daňová optimalizace nadnárodních společností prostřednictvím vnitřních cen: přehled hlavních teoretických východisek a možných makroekonomických dopadů, Politická ekonomie 56(1): 40-53. https://doi.org/10.18267/j.polek.629

Pangarkar, N.; Lim, H. 2003. Performance of foreign direct investment from Singapore, International Business Review 12(5): 601-624. https://doi.org/10.1016/S0969-5931(03)00078-7

Panik, M. J. 2005. Advanced statistics from elementary point of view. London: Elsevier Academic Press.

Pavlínek, P. 2002. The role of foreign direct investment in the privatisation and restructuring of the Czech Motor Industry, Post-Communist Economies 14(3): 359-379. https://doi.org/10.1080/1463137022000013421

Pavlínek, P.; Smith, A. 1998. Internationalization and embeddedness in East-Central European transition: The contrasting geographies of inward investment in the Czech and Slovak Republics, Regional Studies 32(7): 619-638. https://doi.org/10.1080/00343409850119517

Pearson, K. 1904. On the theory of contingency and its relation to association and normal correlation. London: Dulau, Company.

Perkmann, M. 2006. Extraregional linkages and the territorial embeddedness of multinational branch plants: Evidence from the South Tyrol Region in Northeast Italy, Economic Geography 82(4): 421441. https://doi.org/10.1111/j.1944-8287.2006.tb00324.x

Pim, F.; Llinares, E.; Gonnet, S. 2008. PEs and transfer pricing: The playing field in international taxation redefined, Tax Planning International Transfer Pricing 12(12): 1-6. 
Rajnoha, R.; Drábek, J.; Sujová, A.; Merková, M.; Simanová, L.; Volčko, I. 2013. Measurement and management of business performance. Zvolen: Technical University in Zvolen.

Rajnoha, R.; Lesníková, P. 2016. Strategic performance management system and corporate sustainability concept - specific parametres in Slovak Enterprises, Journal of Competitiveness 8(3): 107-124. https://doi.org/10.7441/joc.2016.03.07

Rajnoha, R.; Slivková, D.; Dobrovič, J. 2014. Globalization and transfer pricing in multinational corporations in Slovakia and OECD countries - Analytical study and decision-making model on the choice of optimal transfer-pricing method, Ekonomický časopis/Journal of Economics 62(6): 609-630.

Rajnoha, R.; Štefko, R.; Merková, M.; Dobrovič, J. 2016. Business intelligence as a key information and knowledge tool for strategic business performance. E + M Ekonomie a Management 19(1): 183-203. https://doi.org/10.15240/tul/001/2016-1-013

Rothaermel, F. T. 2001. Complementary assets, strategic alliances, and the incumbent's advantage: an empirical study of industry and firm effects in the biopharmaceutical industry, Research policy 30(8): 1235-1251. https://doi.org/10.1016/S0048-7333(00)00142-6

Rugraff, E. 2008. Are the FDI policies of the Central European countries efficient? Post-Communist Economies 20(3): 303-316. https://doi.org/10.1080/14631370802281415

Rybář, M. 2011. National determinants of international preferences in post-communist Europe: The case of Slovakia in the European Union, Communist and Post-Communist Studies 44(3): 161-171. https://doi.org/10.1016/j.postcomstud.2011.06.001

Simmons, R. 2006. Does recent empirical evidence support the existence of international corporate tax competition?, Journal of International Accounting, Auditing and Taxation 15(1): 16-31. https://doi.org/10.1016/j.intaccaudtax.2006.01.002

Šoltés, V.; Gavurová, B. 2015. Modification of performance measurement system in the intentions of globalization trends, Polish Journal of Management Studies 11(2): 160-170.

Štefko, R.; Slusarczyk, B.; Kot, S.; Kolmasiak, C. 2012. Transformation on steel products distribution in Poland and Slovakia, Metalurgija 51(1): 133-136.

Tuček, D.; Hájková, M.; Tučková, Z. 2013. Utilization level of Business management in Czech enterprises - objectives and factors, $E+M$ Ekonomie a Management 16(2): 81-98.

UNCTAD. 2013. Global Investment Report 2013. Global value chains: Investment and trade for development. Geneva and New York: United Nations.

Urquía Grande, E. et al. 2011. The impact of Accounting Information Systems (AIS) on performance measures: empirical evidence in Spanish SMEs, The International Journal of Digital Accounting Research 11: 25-43. https://doi.org/10.4192/1577-8517-v11_2

Virglerová, Z.; Dobeš, K.; Vojtovič, S. 2016. The perception of the states influence on its business environment in the SMEs from Czech Republic, Administratie si Management Public 14(26): 78-96.

Virglerová, Z.; Homolka, L.; Smrčka, L.; Lazányi, K.; Klieštik, T. 2017. Key determinants of the quality of business environment of SMEs in the Czech Republic, E \& M Ekonomie a Management 20(2): 87-100. https://doi.org/10.15240/tul/001/2017-2-007

Zajac, Š.; Baláž, V. 2007. Dual economy and impacts of foreign investment on private R\&D in Slovakia, Ekonomický časopis/Journal of Economics 55(9): 851-872.

Zámečník, R.; Rajnoha, R. 2015. Strategic business performance management on the base of controlling and managerial information support, Procedia Economics and Finance 26: 769-776. https://doi.org/10.1016/S2212-5671(15)00843-6

Žižka, M.; Hovorková, V.; Turčok, L. 2016. Performance evaluation of Czech innovative companies: data envelopment analysis approach, International Journal of Strategic Property Management 20(4): 427-438. https://doi.org/10.3846/1648715X.2016.1239592 